\title{
In Vivo Analysis of Antibacterial Silver Coated Titanium Implants in a Contaminated Rabbit Knee Model
}

\author{
Antibakteriyel Gümüş Kaplı \\ Titanyum İmplantların \\ Kontamine Tavşan Diz Modelinde \\ İn Vivo Analizi
}

\section{Ozan BiTiK, ${ }^{a}$ \\ Hakan UZUN, ${ }^{a}$ \\ Abdullah KEÇiKa}

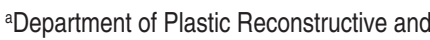
Aesthetic Surgery,

Hacettepe University Faculty of Medicine, Ankara

Geliş Tarihi/Received: 25.08 .2013

Kabul Tarihi/Accepted: 23.10.2013

Yazışma Adresi/Correspondence: Ozan BiTiK

Hacettepe University Faculty of Medicine Department of Plastic Reconstructive and Aesthetic Surgery, Ankara,

TÜRKIYE/TURKEY

bitikozan@hotmail.com

\begin{abstract}
Objective: In this study, it was hypothesized that sol-gel silver coated titanium implants showed a better antibacterial activity compared to standard titanium implants in contaminated surgical fields. Material and Methods: Twenty four New Zelland Albino rabbits were used in the experiment. Right knees of the rabbits were determined as the control group and left knees were determined as the experiment group. Total knee replacement arthroplasty was performed by using a custom made titanium implant the control group. In the experiment group the same procedure was performed by using sol-gel antibacterial silver coated titanium implants. Following implantation, both groups were inoculated with bacterial suspensions containing standardised bacterial loads of $S$. aureus and $P$. aeruginosa. Animals were observed for general condition, body temperature, weight and clinical signs of implant infection for 12 weeks. Clinical signs of infection were further evaluated with microbiological tests. Results: Total infection rates, $S$. aureus-specific infection rates and $P$. aeruginosa-specific infection rates were significantly lower in sol-gel silver coated titanium implants. No statistically significant difference was found between the groups in terms of subclinical infection rates. Conclusion: We concluded that sol-gel silver coating of the titanium implants was effective against two common agents causing implant infections.
\end{abstract}

Key Words: Biocompatible materials; arthroplasty, replacement, knee; bacterial infections; silver

ÖZET Amaç: Bu çalışmanın hipotezi, sol-gel antibakteriyel gümüş kaplı titanyum implantların kontamine cerrahi alanlarda standart titanyum implantlara kıyasla enfeksiyona daha dirençli olabileceğidir. Gereç ve Yöntemler: Deneyde 24 adet Yeni Zellanda albino tavşanı kullanıldı. Tavşanların sağ diz eklemi kontrol, sol diz eklemleri ise deney grubu olarak atandı. Kontrol grubunda özel tasarım titanyum implant ile total diz artroplastisi uygulandı. Deney grubunda aynı işlem sol-gel antibakteriyel gümüş kaplı titanyum implantlar ile gerçekleştirildi. İmplantasyonu takiben her iki grup da standart bakteri yükünde $S$. aureus ve $P$. aeruginosa içeren bakteriyel süspansiyonlar ile inoküle edildi. Hayvanlar işlem sonrasında genel durum, vücut 1sısı, ağırlık ve implant enfeksiyonunun klinik bulguları açısından 12 hafta süreyle gözlemlendi. Enfeksiyonun klinik bulgularının gözlendiği deneklerde mikrobiyolojik tetkikler yapıldı. Bulgular: Sol-gel antibakteriyel gümüş kaplı titanyum implantlarda toplam enfeksiyon, $S$. aureus spesifik ve $P$. aeruginosa spesifik enfeksiyon oranları, kontrol grubuna göre daha düşük bulundu. Enfeksiyonların çoğunluğu subklinik vasıfta idi. Gruplar arasında subklinik enfeksiyon oranları arasında farklılık saptanmadı. Sonuç: Bu çalışmada elde edilen bulgular ile, sol-gel gümüş kaplamanın, titanyum implantların enfeksiyon direncini arttırdığı sonucuna varıldı.

Anahtar Kelimeler: Biyouyumlu materyaller; artroplasti, yerine koyma, diz; bakteri enfeksiyonları; gümüş

Turkiye Klinikleri J Med Sci 2013;33(6):1462-72

T itanium implants are among the most commonly used bio-materials in the surgical field. Infection is by far the most important problem regarding the use of titanium implants. With the advent of sterility 
and antibiotics, infectious complications associated with alloplastic implantation have been minimized and titanium implant-reinforced bone repair has evolved to become an integral part of the standard modern surgical practice. ${ }^{1}$ However, implant infections still pose a devastating risk, especially for those procedures in which the salvage of an extremity depends on the success of implantation.

Resurfacing the titanium implants with antibacterial materials had been an extensively studied strategy in the quest to inhibit bacterial adhesion and to further reduce the rate of implant infections. Silver is one of the oldest and the most commonly used antibacterial coating materials. Silver-coated titanium implants are currently being used in surgical practice, however, indications are limited to sterile elective procedures. Although there are clinical studies in the literature which support their ability to reduce postoperative infection rates in sterile surgical fields, there are no clinical data which support their efficacy in contaminated surgical fields, ironically, where they are needed the most.

Plastic surgery is a discipline which frequently performs fracture repairs and bone reconstructions in contaminated surgical fields. The contamination can arise from normal flora in the case of comminuted jaw fractures or from the environment in the case of limb and finger re-plantations. Rigid fixation with titanium implants in such contaminated fields is classically associated with increased morbidity, mainly due to implant infection-based complications. Our experiment model was designed in consideration with the needs of modern plastic surgery and hand surgery practice and their future clinical directions. Our study aims to test the antibacterial efficacy of silver coated titanium implants in an in vivo contaminated rabbit knee fixation model before proceeding with clinical studies.

\section{MATERIAL AND METHODS}

\section{EXPERIMENT SETUP}

This study was approved by the institutional review board of animal ethics and carried out in the surgical research laboratories of Hacettepe University,
Ankara, Turkey. Twenty six New Zealand albino rabbits, each weighing between 3500-5200 grams were used. All animals were checked for signs of infection prior to inclusion. All animals were kept in standardized conditions, at room temperature, one animal per one $0.6 \mathrm{~m}^{2}$ cage. Standard animal food and tap water were used for nutrition. Animals were fasted six hours prior to surgery. Antibiotic prophylaxis was not used. Two of 14 animals were used for a preliminary anatomical study, in which surgical anatomy of the rabbit knee was explored, and implants and surgical approach were tested.

\section{GROUPS}

Twenty four rabbits were used in the experimental phase of the study. Right knee joints of these animals were designed as the control group and replaced with titanium knee implants. Left knee joints of the animals were designed as the experiment group and replaced with sol-gel silver coated titanium knee implants.

\section{ANTIBACTERIAL COATING}

Titanium knee implants in the experiment group were coated with silver by using sol-gel method. (Norm medical devices Ltd, Ankara, Türkiye, CE 1011 No: 5-454-200-0602, ISO 9001 No:39242)

\section{TITANIUM IMPLANT}

Titanium implants used in this study have been designed for total knee arthroplasty in accordance with the reference anthropometric measurements of New Zealand albino rabbits. The knee arthroplasty implant is composed of three pieces, a Tshaped articular piece, a Y-shaped articular piece and a connection pin (Figure 1). The implant was manufactured by Trimed, Ankara, Turkey, on a five axis CNC machine from Ti4Al6V (ASTM F136) medical grade titanium alloy. The Y-shaped proximal component was integrated on a $20 \mathrm{~mm}$ long straight screw, diameter of which was $3.5 \mathrm{~mm}$. The $\mathrm{T}$ - shaped distal component was integrated on a 15 $\mathrm{mm}$ long tapered screw, diameter of which decreased from $3 \mathrm{~mm}$ proximal to $2 \mathrm{~mm}$ distally. In order to reduce post-implantation loosening, both screws were rabbeted clockwise. Implant range of motion was between 0-105 degrees (Figures 2,3). 


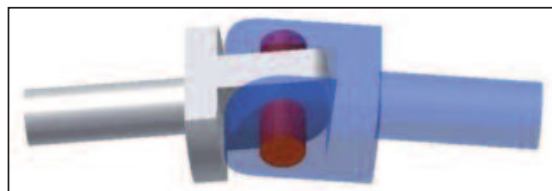

FIGURE 1: Schematic representation of the titanium total knee arthroplasty implant. The central pin which is illustrated in red is designed to be removed and sent for an aerobe culture after explantation.

(See color figure at http://www.turkiyeklinikleri.com/journal/tip-bilimleri-dergisi/1300-0292/)

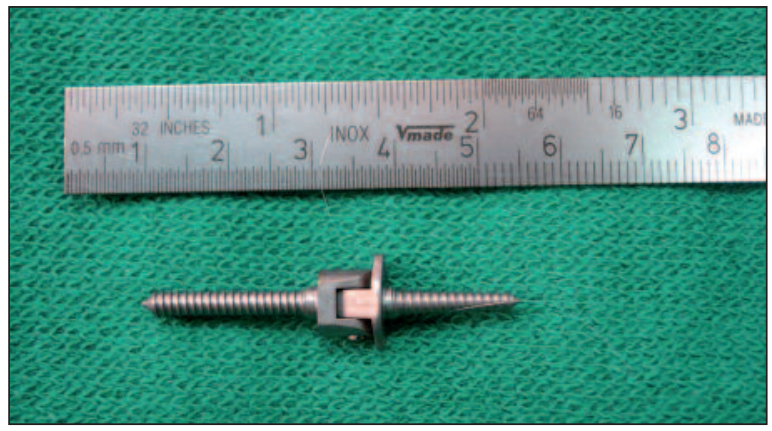

FIGURE 2: Anteroposterior view of the silver coated titanium implant. (See color figure at http://www.turkiyeklinikleri.com/journal/tip-bilimleri-dergisi/1300-0292/)

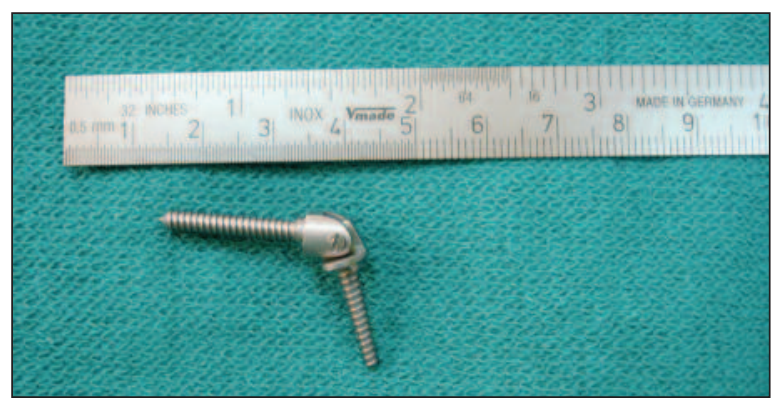

FIGURE 3: Side view of the silver coated titanium implant.

(See color figure at http://www.turkiyeklinikleri.com/journal/tip-bilimleri-dergisi/1300-0292/)

\section{ANESTHESIA}

Anesthesia was induced by intramuscular injections of xylazine (30 mg/kg, Rompun ${ }^{\circledR}$, Bayer, Germany) and ketamine $\left(50 \mathrm{mg} / \mathrm{kg}\right.$, Ketalar ${ }^{\circledR}$, Eczacıbaşı, Istanbul, Türkiye). Depth of anesthesia was monitored by observing the lower extremity retraction reflex, urinary and fecal incontinence, and in the event of these observations, one-third of the induction dose was administered for maintenance.

\section{SURGICAL TECHNIQUE}

Following induction of anesthesia, the surgical field was prepared with povidone iodine solution, and draped respecting sterility (Figure 4a). The skin was incised and the flaps were retracted to expose the patellar tendon. A U-shaped incision was made on the dorsal surface of the knee joint dividing the patellar tendon, joint capsule and collateral ligaments (Figure 4b). The joint segment which was planned to be resected was sharply dissected from the surrounding soft tissues. A blunt tip mosquito clamp was inserted posteriorly towards the undersurface of the joint to bluntly separate the popliteal neurovascular structures (Figure 4c). Following this maneuver, tibial and femoral condyles along with $5 \mathrm{~mm}$ bone segments on both sides were resected en-bloc to create the defect for the total knee arthroplasty (Figures 4d, 4e).

Following resection, proximal and distal components were rigidly screwed into the medullary cavity and the central pin was inserted to assemble the implant (Figure 4f). Following fixation, collateral ligaments were repaired with 3.0 and the patellar tendon was repaired using 2.0 prolene sutures, reconstituting joint stability (Figure $4 \mathrm{~g}$ ). Skin was repaired with 3.0 silk sutures.

\section{CONTROLLED CONTAMINATION}

Implants in experiment and control groups were contaminated with bacterial suspensions containing Staphylococcus aureus and Pseudomonas

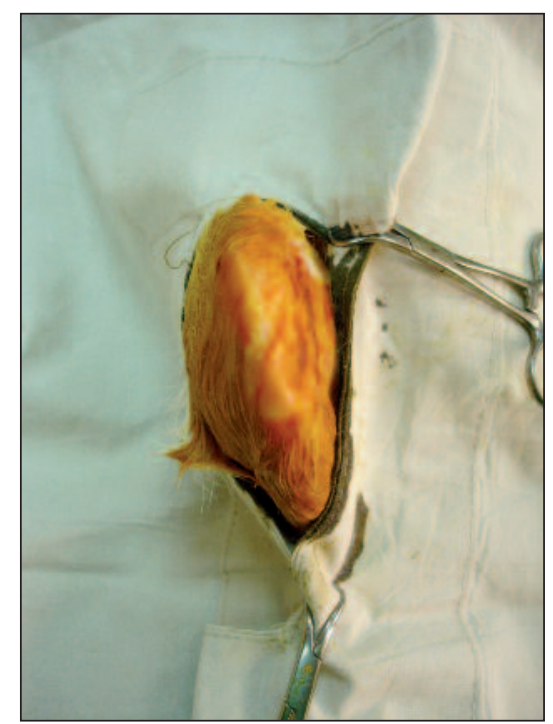

FIGURE 4a: Sterile preparation and draping.

(See color figure at http://www.turkiyeklinikleri.com/journal/tip-bilimleri-dergisi/1300-0292/) 


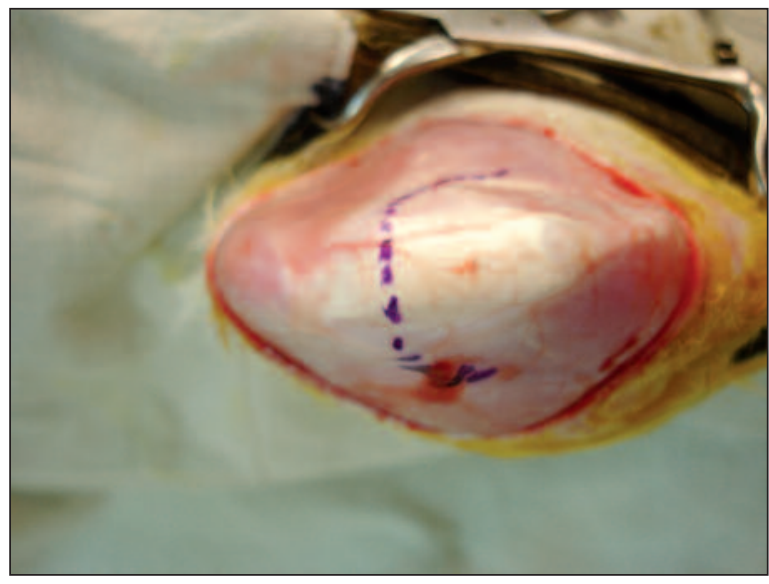

FIGURE 4b: U-shaped incision plan on the patellar tendon and joint capsule. (See color figure at http://www.turkiyeklinikleri.com/journal/tip-bilimleri-dergisi/1300-0292/)

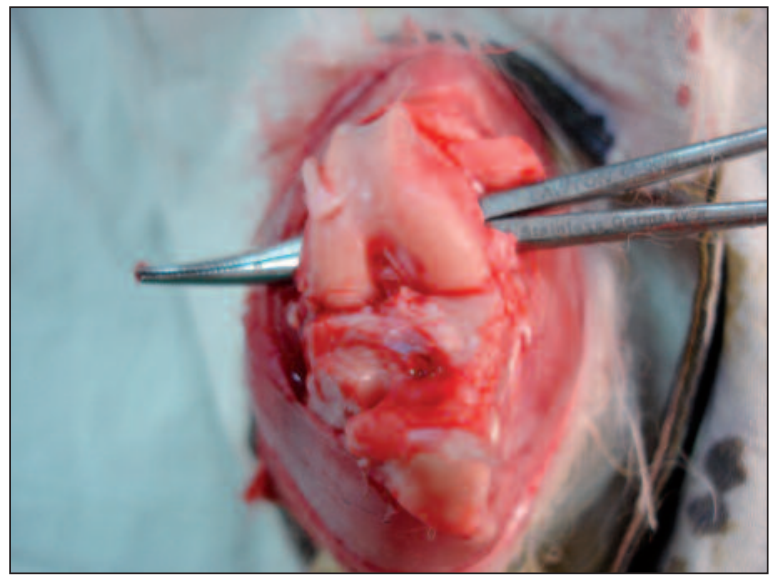

FIGURE 4c: Joint structures were dissected from the surrounding soft tissues. Popliteal vessels were bluntly separated and protected.

(See color figure at http://www.turkiyeklinikleri.com/journal/tip-bilimleri-dergisi/1300-0292/)

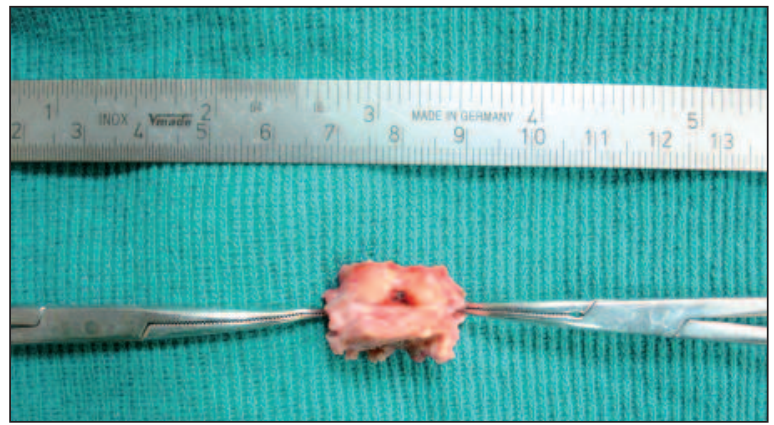

FIGURE 4d: En-bloc knee joint resection.

(See color figure at http://www.turkiyeklinikleri.com/journal/tip-bilimleri-dergisi/1300-0292/)

aeruginosa. Bacterial loads for each species were determined by the reference levels previously published in the literature..$^{2-4}$ Contamination process

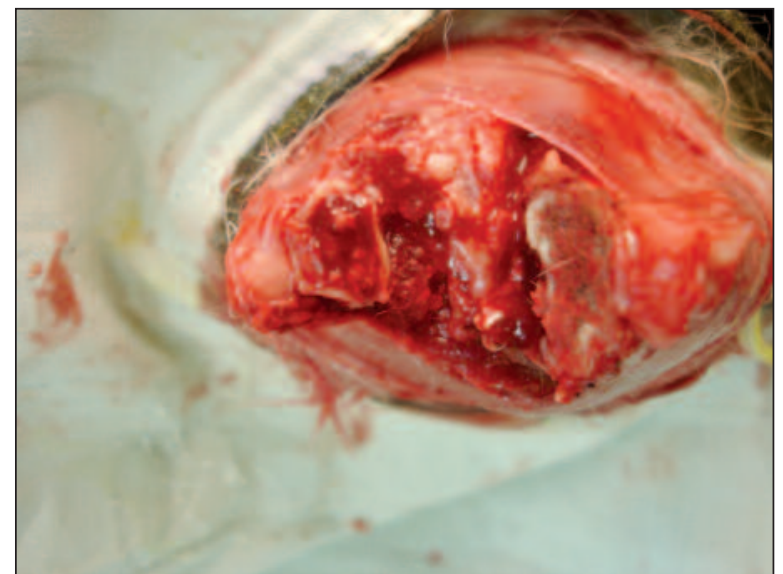

FIGURE 4e: Total knee defect.

(See color figure at http://www.turkiyeklinikleri.com/journal/tip-bilimleri-dergisi/1300-0292/)

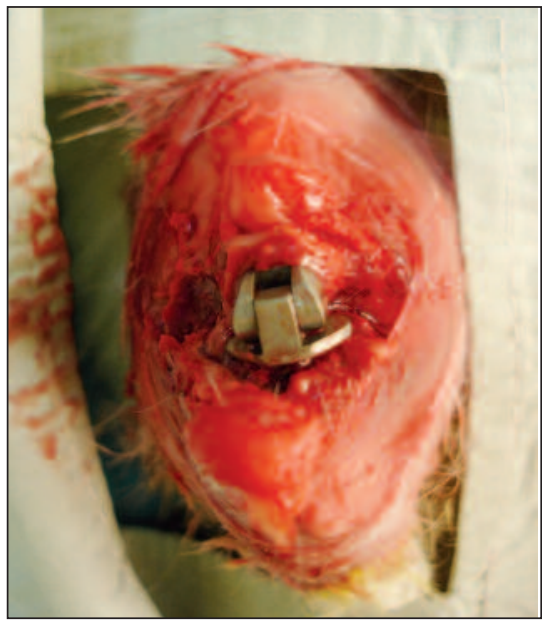

FIGURE 4f: The implant has been screwed and assembled.

(See color figure at http://www.turkiyeklinikleri.com/journal/tip-bilimleri-dergisi/1300-0292/)

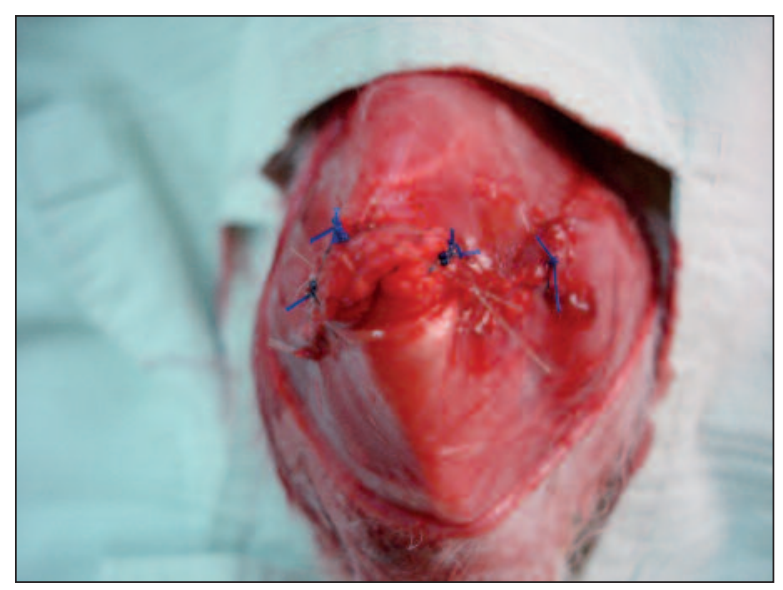

FIGURE 4g: Repair of the joint capsule, collateral ligaments and the patellar tendon.

(See color figure at http://www.turkiyeklinikleri.com/journal/tip-bilimleri-dergisi/1300-0292/) 
was undertaken by injecting into the joint capsule using a $30 \mathrm{G}$ needle and a $0.5 \mathrm{~mL}$ syringe, after surgical closure of the wound in order to increase accuracy. Pathogenic bacteria were cultivated from the cultures of an inpatient who was being followed for purulent talo-calcaneal implant-related osteomyelitis in Hacettepe University Adult Hospital.

Staphylococcus aureus was cultivated as follows: Bacterial samples were transferred from the clinical culture into a plate count agar (Tryptone, Glucose, Yeast, Agar, Oxoid) stock culture medium, and incubated overnight. Petroff Hausser lamella was used to assess bacterial concentration which was $10^{8} \mathrm{CFU} / \mathrm{mL}$. This stock culture was diluted in a 1/10 000 ratio with Maximum Recovery Diluent (Peptone, $\mathrm{NaCl}$, Oxoid) to arrive at a $10^{4}$ $\mathrm{CFU} / \mathrm{mL}$ working culture. Both knees were injected with $0.2 \mathrm{~mL}\left(2 \times 10^{3} \mathrm{CFU}\right)$ of this bacterial suspension. $P$. aeruginosa was cultivated using the same methodology, to arrive at a final concentration of $2 \times 10^{7} \mathrm{CFU}$ in $0.2 \mathrm{~mL}$.

\section{POST-SURGICAL FOLLOW UP}

Soon after recovery from surgical anesthesia, animals were transferred into standard cages and postoperative analgesia was maintained by oral administration of parasetamol which was added into their drinking water to obtain a dose of 2 $\mathrm{mg} / \mathrm{mL}$. During the first 6 weeks, animals were kept in standard cages, after that, they were kept in larger cages which allowed increased mobility and increased load-bearing of the implanted knee. Animals were weekly examined for general well being, body weight, posture, body temperature and signs of infection. Temperature measurements were made by using a digital thermometer from each ear. Duration of follow up was designed to be 12 weeks, the time when osseous integration of titanium implants became mature. When any sign of infection was observed, either local or systemic, three samples were obtained from each knee joint and sent for aerobic and anaerobic cultures. In the case of a purulent discharge or a wound breakdown, the samples were collected by using a swab. In the case of a clinically normal knee joint, sam- ples were collected by irrigating and re-aspirating the joint with $1 \mathrm{~mL}$ of sterile distilled water. At the end of 12 weeks, all animals were sacrificed under general anesthesia by means of exsanguination from femoral vessels. During sacrification, central pins were removed bilaterally and sent for culture. Same procedure was followed for animals who died during experiment period, as well.

\section{STATISTICAL ANALYSIS}

Statistical analysis was performed using SPSS software (Statistical Package for Social Sciences 10.0). Infection rates between groups were compared using Fisher's Exact test. This test was preferred over Chi-square due to the expectancy that more than $20 \%$ of frequencies in the cross table were smaller than 5 .

\section{RESULTS}

\section{CLINICAL OBSERVATIONS (TABLE 1)}

The mean body weight of the animals was $4260 \mathrm{~g}$ at the beginning of the study. At postoperative $7^{\text {th }}$ day, the mean body weight was $4246 \mathrm{~g}$, and that was the lowest weight. At postoperative $4^{\text {th }}$ week, the mean body weight returned to preoperative values, and at the end of 12 weeks it increased up to $4390 \mathrm{~g}$. The mean body temperature was within normal physiologic limits of $38.5-39.5^{\circ} \mathrm{C}$, in all animals. Weekly posture examinations were found to be in normal implant range of $0-105^{\circ}$.

At day 6, the animal numbered as 20 was observed to have wound dehiscence on the right knee joint (control group) and the implant was exposed. Swab cultures were obtained from the right knee and irrigation/aspiration cultures were obtained from the left knee, and sent for culture. The cultures of both control and experiment knee joints were positive for $S$. aureus. The animal was sacrificed and central pins were bilaterally sent for a confirmation culture. The confirmation cultures were also positive for $S$. aureus at both knee joints.

At day 8 , the animal numbered as 7 was observed to have wound dehiscence on the right knee joint (control group) and the implant was exposed (Figure 5a). Swab cultures were obtained from the 


\begin{tabular}{|c|c|c|c|}
\hline & Clinical course & Right Knee (Control) Ti & Left Knee(Experiment) Ti+Silver \\
\hline Animal 1 & Sacrificed at the $12^{\text {th }}$ week & $S A \& P A$ & $S A$ \\
\hline Animal 2 & Sacrificed at the $12^{\text {th }}$ week & $S A$ & Negative cultures \\
\hline Animal 3 & Sacrificed at the $12^{\text {th }}$ week & $S A$ & $S A$ \\
\hline Animal 4 & Sacrificed at the $12^{\text {th }}$ week & $S A \& P A$ & Negative cultures \\
\hline Animal 5 & Sacrificed at the $12^{\text {th }}$ week & SA\&PA & $S A$ \\
\hline Animal 6 & Sacrificed at the $12^{\text {th }}$ week & $S A$ & $S A$ \\
\hline Animal 7 & Dehiscence on the right knee at day 8 & $P A$ & $S A$ \\
\hline Animal 8 & Exitus on the $64^{\text {th }}$ day & $S A$ & $S A$ \\
\hline Animal 9 & Sacrificed at the $12^{\text {th }}$ week & $S A \& P A$ & $S A$ \\
\hline Animal 10 & Sacrificed at the $12^{\text {th }}$ week & $S A \& P A$ & Negative cultures \\
\hline Animal 11 & Dehiscence on the right knee at day 10 & $S A \& P A$ & $S A$ \\
\hline Animal 12 & Sacrificed at the $12^{\text {th }}$ week & $S A$ & $S A$ \\
\hline Animal 13 & Sacrificed at the $12^{\text {th }}$ week & $S A \& P A$ & $S A$ \\
\hline Animal 14 & Sacrificed at the $12^{\text {th }}$ week & $S A$ & $S A$ \\
\hline Animal 15 & Sacrificed at the $12^{\text {th }}$ week & SA\&PA & $S A$ \\
\hline Animal 16 & Sacrificed at the $12^{\text {th }}$ week & $S A \& P A$ & Negative cultures \\
\hline Animal 17 & Exitus on the $31^{\text {st }}$ day & $S A$ & Negative cultures \\
\hline Animal 18 & Sacrificed at the $12^{\text {th }}$ week & $S A$ & Negative cultures \\
\hline Animal 19 & Sacrificed at the $12^{\text {th }}$ week & $S A$ & $S A$ \\
\hline Animal 20 & Dehiscence on the right knee at day 6 & $S A$ & $S A$ \\
\hline Animal 21 & Sacrificed at the $12^{\text {th }}$ week & SA\&PA & $S A$ \\
\hline Animal 22 & Sacrificed at the $12^{\text {th }}$ week & $S A$ & Negative cultures \\
\hline Animal 23 & Sacrificed at the $12^{\text {th }}$ week & $S A$ & $S A$ \\
\hline Animal 24 & Sacrificed at the $12^{\text {th }}$ week & $S A \& P A$ & $S A$ \\
\hline
\end{tabular}

SA: Staphylococcus aureus; PA: Pseudomonas aeruginosa; Ti: Titanium implant; Ti+Silver: Silver coated titanium implant.

right knee and irrigation/aspiration cultures were obtained from the left knee, and sent for culture. The culture of the right knee (control group) was positive for $P$. aeruginosa, and the culture of the left knee (experiment group) was positive for $S$. aureus. Since both cultures were positive, the animal was sacrificed and the central pins were sent for a confirmation culture. The confirmation culture was positive for $P$. aeruginosa at the right knee (control) and positive for $S$. aureus at the left (experiment).

At day 10, the animal numbered as 11 was observed to have wound dehiscence on the right knee joint (control group) and the implant was exposed (Figure5b). Swab cultures were obtained from the right knee, and irrigation/aspiration cultures were obtained from the left knee, and sent for culture. The cultures of the right knee (control group) was positive for both $P$. aeruginosa and $S$. aureus, and the cultures of the left knee (experiment group) was positive for $S$. aureus. Since both cultures were positive, the animal was sacrificed and the central pins were sent for culture for further confirmation. The confirmation cultures were positive for both $P$. aeruginosa and $S$. aureus at the right knee (control), and positive for $S$. aureus at the left (experiment).

The animal numbered as 8 died on the postoperative day 64. Both knee joints were irrigated, aspirated, and aspirates were sent for cultures. Then, both implants were explored and central pins were removed and sent for confirmation culture. Cultures were positive bilaterally for $S$. aureus.

The animal numbered as 17 died on the postoperative day 31. Both knee joints were irrigated, aspirated, and aspirates were sent for cultures. 


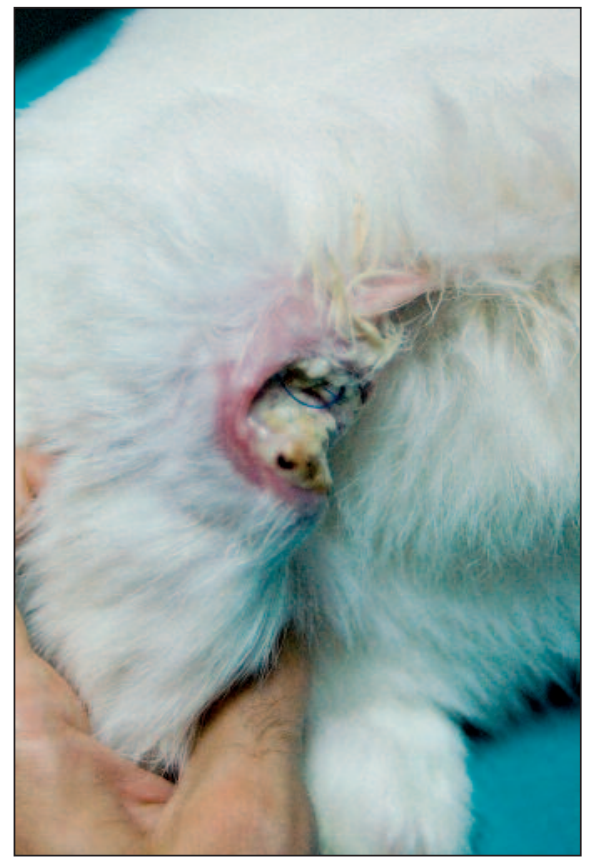

FIGURE 5a: Purulent infection and wound dehiscence in the animal numbered as 7 on day 8 .

(See color figure at http://www.turkiyeklinikleri.com/journal/tip-bilimleri-dergisi/1300-0292/)

Then, both implants were explored, and central pins were removed and sent for confirmation cultures. The culture of the right knee was positive for $S$. aureus while the cultures were negative for both organisms at the left knee.

Remaining animals were sacrificed at the end of $12^{\text {th }}$ week, and the same protocol was followed for each of them.

\section{MICROBIOLOGIC FINDINGS (TABLE1)}

General infection rate was $100 \%$ in the control group and $70.8 \%$ in the experiment group. Silver coated implants in the experiment group had a significantly lower rate of infection $(\mathrm{p}<0.05)$ (Table 2).

$P$. aeruginosa-specific infection rate was $50 \%$ in the control group and $0 \%$ in the experiment group. In the experiment group, silver coated implants had a significantly lower $P$. aeruginosa infection rate $(\mathrm{p}<0.05)$ (Table 3$)$.

$S$. aureus-specific infection rate was $95.8 \%$ in the control group, and $70.8 \%$ in the experiment group. Silver coated implants in the experiment group had a significantly lower rate of $P$. aeruginosa infection $(\mathrm{p}<0.05)$ (Table 4).

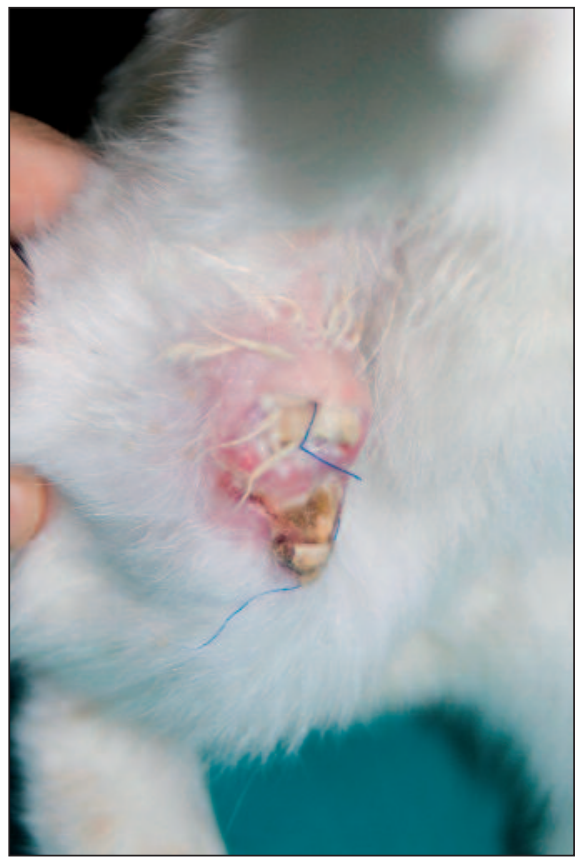

FIGURE 5b: Purulent infection and wound dehiscence in the animal numbered as 11 on day 10 .

(See color figure at http://www.turkiyeklinikleri.com/journal/tip-bilimleri-dergisi/1300-0292/)

\begin{tabular}{|lccc|}
\hline \multicolumn{4}{|c|}{ TABLE 2: } \\
Comparison of groups in terms of \\
general infection rates.
\end{tabular}

Ti+Silver: Silver coated titanium implant.

TABLE 3: Comparison of groups in terms of Pseudomonas aeruginosa specific infection rates.

\begin{tabular}{lccc|}
\hline & P. aeruginosa + & P. aeruginosa - & Total \\
Experiment (Ti+Silver) & 0 & 24 & 24 \\
Control (Ti) & 12 & 12 & 12 \\
Total & 12 & 36 & 24 \\
& $\mathrm{p}<0.0001$ & & \\
\hline
\end{tabular}

Ti+Silver: Silver coated titanium implant.

The total rate for subclinical infection was $92.6 \%$. The subclinical infection rate was $87.5 \%$ in the control group and $100 \%$ in the experiment group. However, this difference was not statistically significant $(\mathrm{p}=0.253)$ (Table 5$)$. 
TABLE 4: Comparison of groups in terms of S.aureus specific infection rates.

\begin{tabular}{|lccc|}
\hline & S. aureus + & S. aureus - & Total \\
Experiment (Silver+Ti) & 17 & 7 & 24 \\
Control(Ti) & 23 & 1 & 24 \\
Total & 40 & 8 & 48 \\
& $\mathrm{p}=0.047$ & & \\
\hline
\end{tabular}

TABLE 5: Comparison of groups in terms of subclinical infection rates.

\begin{tabular}{lccc|}
\hline & $\begin{array}{c}\text { Subclinical } \\
\text { infection }\end{array}$ & $\begin{array}{c}\text { Clinical } \\
\text { infection }\end{array}$ & Total \\
Experiment (Silver+Ti) & 17 & 0 & 17 \\
Control (Ti) & 21 & 3 & 24 \\
Total & 38 & 3 & 41 \\
& $\mathrm{p}=0.253$ & & \\
\hline
\end{tabular}

\section{DISCUSSION}

Plastic surgery is one of the leading specialities in medicine with regard to its utilization of a large variety of alloplastic materials..$^{5}$ Infection is by far the most common complication of alloplastic implantation, and it is directly associated with contamination. ${ }^{6-11}$ The increased risk of implant infection in the contaminated surgical fields of acute hand and upper extremity trauma precludes the use of rigid fixation tools, and this limitation may hamper functional recovery. ${ }^{12-15}$

In a previous study from our department, two innovative intramedullary phalangeal implants had been designed to enable immediate fixation during finger replantations. Despite their biomechanical and practical advantages, clinical trials with these implants have been postponed due to the increased risk of infection in contaminated fields. Our study also aims to support these previous efforts towards clinical trials. ${ }^{16}$

Identification of bacterial adhesion as the key step in implant infections has shifted the research efforts in this field towards development of preventive strategies. ${ }^{17,18}$ The most common strategy of preventing implant infections is coating the im- plant surface with an antibacterial material. ${ }^{1,5,19-21}$ Up to date, there is no coating which can be applied to all surfaces or effective against all organisms. On the other hand, there are thousands of different coating strategies which have been designed for different surface types and are effective against different organisms. However, only a few of them has made their way through clinical trials and even less is readily available on the market; silver coatings are amongst these few. ${ }^{22}$

The largest clinical trials which aim to test the antibacterial efficacy of silver coatings have been based on the hypotheses that silver coating would reduce the colonization on biomaterial surfaces when they are placed in body cavities. Silver coated endotracheal tubes have been shown to reduce ventilator associated pneumonia in the intensive care unit setting. ${ }^{23}$ Silver coated urinary catheters have been shown to reduce catheter-associated urinary infections and the cost associated with them. ${ }^{24-27}$ Likewise, silver coated and silver ion releasing central venous catheters have been shown to decrease catheter colonization and the incidence of blood borne infections in the oncologic and intensive care settings. ${ }^{28-30}$

In their 2004 in vivo experimental study, Gosheger et al. have investigated the antibacterial efficacy and systemic toxicity of silver coated titanium endoprostheses in a rabbit femoral defect model. ${ }^{2}$ Silver coating was accomplished by galvanic deposition and implants were contaminated with $S$. aureus. Silver coating was shown to reduce infection rates without systemic toxicity. ${ }^{2}$ Supported by these encouraging experimental findings, the same team commenced with clinical trials in their patient group with lower extremity malignancies. Following radical resections, large bony defects were reconstructed with giant silver coated titanium mega-endoprostheses and the extremities were salvaged. In their 2007 and 2010 clinical studies, silver coated titanium tumor prostheses were shown to reduce the rate of implant infections without any systemic toxicity in human subjects..$^{31,32}$

Secinti et al. have investigated the antibacterial efficacy and systemic toxicity of two different 
silver coating methods in two different in vivo experiments. Their experimental model utilized spinal pedicle screws mounted into rabbit iliac crests. In their first study, titanium implants were coated by electroplating and the coating was electrically stimulated to release active ions by anode activation. In their second study, titanium implants were coated with silver nano-particles. Both coatings were shown to reduce the rate of infection without any signs of systemic toxicity. ${ }^{33,34}$

Gailano et al. have investigated the antimicrobial efficacy of nano-particle silver coated intraventricular cerebrospinal drainage catheters in an in vitro model..$^{35}$ The catheters were continuously irrigated with cerebrospinal fluid. and contaminated with $S$. aureus. Silver coated catheters were shown to be significantly less colonized when compared to the standard controls. ${ }^{35}$ Based on this invitro evidence, Keong et al. have conducted a prospective randomized double blind controlled clinical trial on 140 patients. ${ }^{36}$ They showed that the infection rate in the silver nano-particle coated ventricular drainage catheters was significantly lower than the standard controls. ${ }^{36}$

These prior studies have clearly demonstrated that there is no single, gold standard experimental model to test the efficacy and safety of silver coatings, but every team designed its own model to simulate the clinical scenarios in which the implant would be used. The model in our study aimed to simulate the scenario of an acute, contaminated finger trauma in which the interphalangeal joint was irreversibly damaged, and there was a need for a primary prosthetic arthroplasty. Rabbit knee joint is the best match for the human interphalangeal joint.

Our review of literature about the infectious complications in bilateral alloplastic implantations did not yield any data which indicated an increased risk of infection on the contralateral implant when one side was infected. Khan investigated the infection rates in breast implants. In 1628 patients, a total of 3256 implants were used, 52 patients had infection and only one was bilateral. ${ }^{8}$ Huotari et al. reviewed the infection rate in bilateral knee re- placements. ${ }^{37}$ They showed that bilateral implantation was not associated with an increased infection risk, and all infections observed in their 702 patients were unilateral. ${ }^{37}$ Based on these literature findings, Hacettepe University experimental animal ethics committee approved our study design of bilateral implantation. This design reduced the number of animals sacrificed for experimental purposes as well as animal maintenance costs.

Selection of microorganisms for controlled contamination was based on the aforementioned scenario and similar studies in the literature. Staphylococcus aureus, Staphylococcus epidermidis and Pseudomonas aeruginosa are among the most commonly isolated organisms in implant infections. ${ }^{5,6,20,38,39} S$. aureus is the most common cause of implant infections, and it is the main target of antibacterial coating research. $P$. aeruginosa is one of the most important Gram negative organisms in the etiology of bone infections, and it is commonly isolated from mixed osteomyelitis infective floras. Although $S$. epidermidis is another important causative organism in human infections, it is not included in our study because its virulence in New Zealand albino rabbits is unknown.

Bacterial counts $\left(2 \times 10^{3} \mathrm{CFU}\right.$ for $S$. aureus and $2 \times 10^{7}$ for $P$. aeruginosa) used in controlled contamination were determined with reference to the recommended minimum infective doses in prior studies which employed a rabbit osteomyelitis model. ${ }^{3,4}$

All implants in the control group were successfully contaminated, and $100 \%$ infection rate was achieved. The cultures were only positive for the organisms which were used for the contamination. These findings confirm the proper design of our control groups.

Our follow-up design was based on the principle that if a biofilm is formed on the surface of an implant, it will be present at the time of sacrification regardless of the duration of follow-up. The clinical presentation of implant infections is influenced by many host -specific factors such as systemic and local immunity or density of fibrous encapsulation. Since our aim was to test the effi- 
cacy of antibacterial coating on total infection rates, biochemical or radiological interventions for the early detection of subclinical infections were not necessary. Subclinical infection rates were not statistically different between the groups in our study, and it was concluded that the silver coating itself had no effect on the clinical presentation.

Silver coating significantly reduced $P$. aeruginosa- related implant infections. Our findings were consistent with prior clinical and in-vitro studies in the literature. ${ }^{40} P$. aeruginosa is the main gram negative pathogen which causes skin graft lysis in burn wounds, and silver containing topical preparations are well known to be highly effective against it. ${ }^{41,42}$

Silver coating significantly reduced $S$. aureus infections. Since $S$. aureus is the main pathogen in implant infections, this finding is encouraging for future clinical studies. Although the difference is statistically significant, the infection rate in the experiment group is still too high (70.8\%) to be safely used in the clinical setting. Therefore, the authors cannot recommend using titanium implants in contaminated surgical fields, regardless of its coating status. On the other hand, if an implant must be used, it should better be coated.
Although a number of studies have demonstrated different rates of antibacterial efficacy of silver coatings on titanium surfaces, no in vivo or clinical study has ever demonstrated an absolute protective efficacy. Our opinion is that, for any given coating and material combination, when the virulence of involved organisms increase, the efficacy of coating decreases. Therefore, the coating should be tested against virulent organisms. We have used highly virulent, multi-drug resistant hospital infection strains for both $P$. aeruginosa and $S$. aureus. This can be the reason for our high infection rates although the silver coating was found to be effective.

\section{CONCLUSION}

According to the results reported in this paper, it can be concluded that sol-gel silver coating reduces $P$. aeruginosa and $S$. aureus infection rates on titanium implant surfaces. As can be expected, this efficacy is limited by some environmental and host specific factors such as bacterial virulence, density of contamination, and systemic and local immunity. The additional protection provided by the solgel silver coating can be a distinct advantage in the sterile surgical fields. However, in contaminated surgical fields, any alloplastic material, coated or not, should be used with extreme caution.

\section{REFERENCES}

1. Schierholz JM, Beuth J. Implant infections: a haven for opportunistic bacteria. J Hosp Infect 2001;49(2):87-93.

2. Gosheger G, Hardes J, Ahrens $H$, Streitburger $A$, Buerger $H$, Erren $M$, et al. Silver-coated megaendoprostheses in a rabbit model-- an analysis of the infection rate and toxicological side effects. Biomaterials 2004;25(24): 554756.

3. Norden CW, Keleti E. Experimental osteomyelitis caused by Pseudomonas aeruginosa. J Infect Dis 1980;141(1):71-5.

4. Smeltzer MS, Thomas JR, Hickmon SG, Skinner RA, Nelson CL, Griffith D, et al. Characterization of a rabbit model of staphylococcal osteomyelitis. J Orthop Res 1997;15(3):41421.
5. Eppley BL. Alloplastic implantation. Plast Reconstr Surg 1999;104(6):1761-83; quiz 17845.

6. Darouiche RO. Treatment of infections associated with surgical implants. N Engl J Med 2004;350(14):1422-9.

7. Custer PL, Trinkaus KM. Porous implant exposure: Incidence, management, and morbidity. Ophthal Plast Reconstr Surg 2007;23(1): 1-7.

8. Khan UD. Breast augmentation, antibiotic prophylaxis, and infection: comparative analysis of 1,628 primary augmentation mammoplasties assessing the role and efficacy of antibiotics prophylaxis duration. Aesthetic Plast Surg 2010;34(1):42-7.

9. Stone IE, Dodson TB, Bays RA. Risk factors for infection following operative treatment of mandibular fractures: a multivariate analysis. Plast Reconstr Surg 1993;91(1): 64-8.

10. Furr AM, Schweinfurth JM, May WL. Factors associated with long-term complications after repair of mandibular fractures. Laryngoscope 2006;116(3):427-30.

11. Bui $P$, Demian N, Beetar P. Infection rate in mandibular angle fractures treated with a 2.0$\mathrm{mm} 8$-hole curved strut plate. J Oral Maxillofac Surg 2009;67(4):804-8.

12. Mahan J, Seligson D, Henry SL, Hynes P, Dobbins J. Factors in pin tract infections. Orthopedics 1991;14(3):305-8.

13. Parameswaran AD, Roberts CS, Seligson D, Voor M. Pin tract infection with contemporary external fixation: how much of a problem? J Orthop Trauma 2003;17(7):503-7. 
14. Powerski M, Maier B, Frank J, Marzi I. Treatment of severe osteitis after elastic intramedullary nailing of a radial bone shaft fracture by using cancellous bone graft in Masquelet technique in a 13-year-old adolescent girl. J Pediatr Surg 2009;44(8):E17-9.

15. Tan KJ, Lim CT, Lim AY. The use of muscle flaps in the salvage of infected exposed implants for internal fixation. J Bone Joint Surg Br 2010;92(3):401-5.

16. Kayikçioğlu A, Karamürsel S, Mavili E, Keçik A. Two new intramedullary implant designs for phalanx fixation in digital replantation: an experimental study. Ann Plast Surg 2000;45(3): 258-63.

17. Gristina AG. Biomaterial-centered infection: microbial adhesion versus tissue integration. Science 1987;237(4822):1588-95.

18. Gristina AG, Oga M, Webb LX, Hobgood CD. Adherent bacterial colonization in the pathogenesis of osteomyelitis. Science 1985; 228(4702):990-3.

19. Park JB, Lakes RS. Polymeric implant materials. Biomaterials: An Introduction. $1^{\text {st }}$ ed. New York: Plenum Press; 1992. p.141-67.

20. Harris LG, Richards RG. Staphylococci and implant surfaces: a review. Injury 2006; 37(Suppl 2):S3-14.

21. Hetrick EM, Schoenfisch MH. Reducing implant-related infections: active release strategies. Chem Soc Rev 2006;35(9):780-9.

22. Zhao L, Chu PK, Zhang Y, Wu Z. Antibacterial coatings on titanium implants. J Biomed Mater Res B Appl Biomater 2009;91(1):47080.

23. Kollef MH, Afessa B, Anzueto A, Veremakis C, Kerr KM, Margolis BD, et al.; NASCENT Investigation Group. Silver-coated endotracheal tubes and incidence of ventilator-associated pneumonia: the NASCENT randomized trial. JAMA 2008;300(7):805-13.

24. Karchmer TB, Giannetta ET, Muto CA, Strain BA, Farr BM. A randomized crossover study of silver-coated urinary catheters in hospitalized patients. Arch Intern Med 2000;160(21): 3294-8.

25. Plowman R, Graves N, Esquivel J, Roberts JA. An economic model to assess the cost and benefits of the routine use of silver alloy coated urinary catheters to reduce the risk of urinary tract infections in catheterized patients. J Hosp Infect 2001;48(1):33-42.

26. Rupp ME, Fitzgerald T, Marion N, Helget V, Puumala S, Anderson JR, et al. Effect of silver-coated urinary catheters: efficacy, cost-effectiveness, and antimicrobial resistance. Am J Infect Control 2004;32(8):445-50.

27. Panknin HT. [Silver coated urinary catheters. Clinical effectiveness and cost-benefit analysis]. Med Monatsschr Pharm 2005;28(10): 368-70.

28. Bong JJ, Kite P, Wilco MH, McMahon MJ. Prevention of catheter related bloodstream infection by silver iontophoretic central venous catheters: a randomised controlled trial. J Clin Pathol 2003;56(10):731-5.

29. Rupp ME, Lisco SJ, Lipsett PA, Perl TM, Keating K, Civetta JM, et al. Effect of a secondgeneration venous catheter impregnated with chlorhexidine and silver sulfadiazine on central catheter-related infections: a randomized, controlled trial. Ann Intern Med 2005;143(8): 570-80.

30. Zegelman M, Guenther G, Florek HJ, Orend $\mathrm{KH}$, Zuehlke $\mathrm{H}$, Liewald $\mathrm{F}$, et al. Results from the first in man german pilot study of the silver graft, a vascular graft impregnated with metallic silver. Vascular 2009;17(4):190-6.

31. Hardes J, von Eiff C, Streitbuerger A, Balke M, Budny T, Henrichs MP, et al. Reduction of periprosthetic infection with silver-coated megaprostheses in patients with bone sarcoma. J Surg Oncol 2010;101(5):389-95.

32. Hardes J, Ahrens H, Gebert C, Streitbuerger A, Buerger $\mathrm{H}$, Erren M, et al. Lack of toxicological side-effects in silver-coated megapros- theses in humans. Biomaterials 2007;28(18): 2869-75.

33. Secinti KD, Özalp H, Attar A, Sargon MF. Nanoparticle silver ion coatings inhibit biofilm formation on titanium implants. J Clin Neurosci 2011;18(3):391-5.

34. Secinti KD, Ayten M, Kahilogullari G, Kaygusuz G, Ugur HC, Attar A. Antibacterial effects of electrically activated vertebral implants. J Clin Neurosci 2008;15(4):434-9.

35. Galiano K, Pleifer C, Engelhardt K, Brössner $G$, Lackner $P$, Huck $C$, et al. Silver segregation and bacterial growth of intraventricular catheters impregnated with silver nanoparticles in cerebrospinal fluid drainages. Neurol Res 2008;30(3):285-7.

36. Keong NC, Bulters D, Richards H, Farringdon M, Sparrow O, Hutchinson PJ, et al. The SILVER Trial (Silver Impregnated Line Versus EVD Randomised Trial). Cambridge: Society of British Neurologic Surgeons, Spring Meeting 2010.

37. Huotari K, Lyytikäinen O, Seitsalo S; Hospital Infection Surveillance Team. Patient outcomes after simultaneous bilateral total hip and knee joint replacements. J Hosp Infect 2007; 65(3):219-25.

38. Zimmerli W, Trampuz A, Ochsner PE. Prosthetic-joint infections. N Engl J Med 2004; 351(16):1645-54

39. Peters $G$. Pathogenesis of $S$ epidermidis foreign body infections. Br J Clin Pract Suppl 1988;57:62-5.

40. Thorn RM, Austin AJ, Greenman J, Wilkins JP, Davis PJ. In vitro comparison of antimicrobial activity of iodine and silver dressings against biofilms. J Wound Care 2009;18(8): 343-6.

41. Klasen HJ. A historical review of the use of silver in the treatment of burns. II. Renewed interest for silver. Burns 2000;26(2):131-8.

42. Klasen HJ. Historical review of the use of silver in the treatment of burns. I. Early uses. Burns 2000;26(2):117-30. 